\title{
PENGEMBANGAN PRODUK BROWNIES BAKAR BERBASIS TEPUNG KACANG MERAH TERHADAP DAYA TERIMA KONSUMEN
}

\author{
Santi Oktaviani, Woro Priatini, Wendi Andriatna \\ Program Studi Manajemen Industri Katering \\ Fakultas Pendidikan Ilmu Pengetahuan Sosial \\ Universitas Pendidikan Indonesia
}

Oktavianisanti80@yahoo.com

\begin{abstract}
ABSTRAK
Penelitian ini bertujuan untuk mengetahui cara pembuatan tepung kacang merah dan konsentrasi tepung kacang merah yang terbaik dalam pembuatan Brownies Bakar, sehingga produk inovasi Brownies Bakar Tepung Kacang Merah dapat disukai panelis dan dapat diterima oleh para konsumen.

Metode penelitian yang digunakan dalam penelitian ini adalah metode penelitian eksperimental. Dengan mengambil populasi yaitu 15 orang panelis ahli untuk menilai konsentrat produk terbaik dari tiga sampel di chef Papandayan Hotel, dosen atau guru yang berhubungan dalam bidang pastry, dan wiraswasta yang berhubungan dalam usaha pastry. Disebarkan kepada 100 orang responden untuk membandingkan konsentrat terbaik dengan produk kontrol dan untuk mengetahui daya terima konsumen. Metode pengumpulan data dilakukan dengan membagikan kuisioner kepada panelis ahli dan responden. Metode analisis data yang digunakan yaitu uji hedonik Analisis Varian (ANOVA) dan uji t, Least Significant Difference (LSD), uji daya terima konsumen dan untuk aspek finansialnya menggunakan perhitungan HPP, BEP, PP dan ROI dengan bantuan Microsoft Excel 2010 dan dengan software SPSS.22 (Statistical Product for Service Solution).

Dari hasil penelitian yang diperoleh, Brownies Bakar Tepung Kacang Merah yang mempunyai konsentrasi terbaik yaitu Brownies Bakar yang memiliki perbandingan $1: 2$ (20 gr tepung terigu dan 40 gr tepung kacang merah).

Kata Kunci : Pengembangan Produk, Brownies Bakar, Berbasis, Tepung Kacang Merah, Daya Terima Konsumen

\section{PENDAHULUAN}

Kota Bandung memiliki banyak variasi oleh-oleh khas Kota Bandung yang bisa dibawa sebagai buah tangan ketika berkunjung ke Kota Bandung dan banyak toko-toko yang menjual berbagai macam oleh-oleh khas Kota Bandung, maka tidak sulit untuk mencari kuliner khas Kota Bandung. Oleh-oleh Kota Bandung yang paling terfavorit dan menjadi pilihan para pelaku bisnis kuliner di Kota Bandung adalah brownies. Brownies kini telah banyak diminati oleh para wisatawan asing maupun para wisatawan lokal saat berkunjung ke Kota Bandung. Tidak lengkap rasanya jika berkunjung ke Kota Bandung tanpa membawa oleh-oleh yang satu ini.

Menurut Noormindhawati (2014, hlm.3) Brownies pada awalnya merupakan cake cokelat yang gagal. Karena teksturnya bantat dan sedikit basah di bagian dalam,
\end{abstract}


tidak sebagaimana cake pada umumnya yang lembut dan berpori. Namun pada kenyataannya, cake jenis ini ternyata dapat diterima dengan baik oleh konsumen. Brownies pertama kali dikembangkan di Amerika pada akhir abad ke-19. Selanjutnya pada abad ke-20, brownies semakin dikenal luas di berbagai negara. Dan kini, brownies semakin kaya rasa dan banyak variannya. Bahkan menjadi salah satu jenis cake yang banyak peminatnya.

Inovasi pengolahan makanan yang berbahan baku kacang merah sangat minim. Pengolahan yang biasa dilakukan terhadap bahan baku kacang merah hanya dibuat sebagai isi onde-onde, selai, dan bubur kacang merah. Maka dari itu dibutuhkan sebuah inovasi yang dapat memanfaatkan potensi serta kelebihan yang dimiliki oleh kacang merah tersebut.

Biji Kacang merah merupakan bahan makanan yang mempunyai energi tinggi dan sekaligus sumber protein nabati yang potensial. Kacang merah dapat digunakan sebagai sayuran (sayur asam atau sup), campuran salad, sambal goreng, kacang goreng, bahan dodol, wajik, dan aneka kue lainnya (Astawan, 2009, hlm.20).

Dari hasil pengamatan penulis, penulis ingin memberikan alternatif pengolahan kacang merah menjadi variasi yang berbeda sebagai penambahan dunia kuliner yang mempunyai kandungan gizi yang baik untuk tubuh. Dengan mempertimbangkan perkembangan potensi daerah dan nilai gizi yang terkandung dalam kacang merah, maka penulis tertarik untuk melakukan percobaan penggunaan kacang merah dalam pembuatan brownies yang biasanya hanya menggunakan tepung terigu saja. Keunikan dari brownies yang menggunakan tepung kacang merah yaitu meningkatkan nilai gizi dan lebih banyak protein nabatinya. Dalam penelitian ini saya menggunakan metode pengolahan melalui pembakaran sehingga biasa disebut brownies bakar, karena aslinya brownies memang dipanggang dan awalnya tercipta dari pembuatan cake yang gagal alias bantat.

Berdasarkan latar belakang di atas, maka penulis tertarik untuk mengambil judul penelitian "PENGEMBANGAN PRODUK BROWNIES BAKAR BERBASIS TEPUNG KACANG MERAH TERHADAP DAYA TERIMA KONSUMEN".

\section{TUJUAN PENELITIAN}

1. Untuk mengetahui proses pembuatan tepung kacang merah pada brownies bakar berbasis tepung kacang merah.

2. Untuk mengetahui formulasi standar resep pada penggunaan tepung kacang merah pada pembuatan brownies bakar.

3. Untuk mengetahui respon daya terima konsumen terhadap brownies bakar berbasis tepung kacang merah.

\section{METODE PENELITIAN}

Metode penelitian ini menggunakan metode pendekatan kuantitatif, karena jenis penelitian ini merupakan penelitian eksperimen serta melakukan uji indrawi atau uji kesukaan kepada panelis dengan menggunakan uji hedonik dan uji organoleptik, kriteria yang diujikan yaitu fisik, warna, rasa, aroma, dan tekstur sehingga dihasilkan suatu formula terbaik. 


\section{Teknis Analisis Data}

Setelah data dari semua panelis terkumpul lalu peneliti mengolah data dengan menggunakan rancangan acak kelompok (RAK) dan menggunakan alat bantu komputer dengan software SPSS.22 (Statistical Product for Service Solution).

\section{Analisis Uji Organoleptik}

Uji organoleptik atau uji indera atau uji sensori merupakan cara pengujian dengan menggunakan indera manusia sebagai alat utama untuk pengukuran daya penerimaan terhadap produk.

Menurut Kartika et al. (1988:20) dalam Widia (2012), pengolahan data untuk Rancangan Acak Kelompok adalah :

$$
\begin{gathered}
\text { FK }=\frac{\left(\sum x\right)^{2}}{T * r} \\
\mathrm{JK}(\mathrm{P})=\frac{(x)^{2}+\ldots+(x)^{2}}{r}-\text { Faktor Koreksi } \\
\mathrm{JK}(\mathrm{S})=\frac{(y)^{2}+\ldots+(y)^{2}}{T}-\text { Faktor Koreksi } \\
\mathrm{JK}(\mathrm{T})=\left(S^{2}+\ldots+S^{2}\right)-\text { Faktor Koreksi }
\end{gathered}
$$

Dimana :

FK = Faktor Koreksi

J.Kuadrat $($ Panelis $)=$ Jumlah Kuadrat Panelis

J.Kuadrat (Sampel) =Jumlah Kuadrat Sampel

J.Kuadrat Total =Jumlah Kuadrat Total

J.Kuadrat Galat =Jumlah Kuadrat Galat

$\mathrm{x}=$ Jumlah penilaian masing-masing panelis terhadap semua sampel

$\mathrm{y}=$ Jumlah penilaian semua panelis terhadap masing-masing produk/sampel

$\mathrm{T}=$ Jumlah Panelis

$\mathrm{r}=$ Jumlah Sampel

$\mathrm{s}=$ Penilaian terhadap sampel

\section{Uji Hedonik (Uji Kesukaan)}

Uji hedonik atau uji kesukaan merupakan pernyataan kesan tentang baik atau buruknya mutu suatu produk. Uji ini dilakukan apabila uji didesain untuk memilih suatu produk diantara produk lain secara langsung. Uji ini dapat diaplikasikan pada saat pengembangan produk atau pembanding produk dengan produk pesaing. Uji kesukaan meminta panelis untuk harus memilih satu pilihan diantara yang lain. Maka itu, produk yang tidak dipilih dapat menunjukan bahwa produk tersebut disukai ataupun tidak disukai (Setyaningsih, dkk, 2010, hlm.59).

Cara analisis uji ini menggunakan uji-t (t-test) untuk membandingkan apakah kedua sampel berasal dari populasi yang sama atau tidak dan mengetahui kebenaran pernyataan atau dugaan yang dihipotesiskan oleh si penulis (Siregar, 2013, hlm.194).

\section{Uji Daya Terima Konsumen}

Data penelitian ini merupakan hasil jawaban responden berdasarkan hasil perhitungan dari penyebaran kuisioner sebanyak 100 kepada konsumen juga dengan 
membagikan sampel. Pada penelitian ini, terdapat lima karakteristik berdasarkan warna, rasa, aroma, tekstur dan penampilan sampel tersebut. Data yang telah terkumpul kemudian di klasifikasikan lalu di analisa dengan menggunakan teknik analisa desktiptif, dengan cara menjumlah semua skor jawaban dari 100 orang responden dengan lima karakteristik pada sampel, selanjutnya dicari interval setiap kelas dengan rumus sebagai berikut:

$\mathrm{C}=\frac{\operatorname{smak}-\operatorname{smin}}{k}$

Keterangan :

C : panjang kelas interval

Smak : skor maksimal

Smin : skor minimum

K : banyaknya kelas

Rumus mencari nilai Smak adalah : $\mathrm{n}$ x k x nilai maksimal

Rumus mencari nilai Smin adalah : $\mathrm{n}$ x k x nilai minimum

Uji Kelayakan Bisnis

Untuk menganalisis studi kelayakan bisnis menggunakan aspek finansial seperti menghitung Harga Pokok Produksi (HPP), Break Event Point (BEP), Payback Period (PP), dan Return on Invesment (ROI).

\section{Break Event Point (BEP)}

Break Event Point (BEP) adalah titik peluang pokok dimana total revenue = total cost. Dilihat dari jangka waktu pelaksanaan sebuah proyek terjadi titik peluang pokok atau TR $=$ TC tergantung pada lama arus penerimaan sebuah proyek dapat menutupi segala biaya operasi dan pemeliharaan beserta biaya modal lainnya.

$$
\begin{aligned}
& \mathrm{BEP}(\text { unit })=\frac{\text { Total Biaya Tetap }}{\text { Harga Jual Perunit }- \text { Biaya Variabel Perunit }} \\
& \mathrm{BEP}(\mathrm{Rp})=\frac{\text { Total Biaya Tetap }}{\text { Kontribusi Margin perunit/HargaJualperunit }}
\end{aligned}
$$

\section{Harga Pokok Produksi (HPP)}

Rumus Harga Produksi Perbulan : $\mathrm{A}=\mathrm{B}+\mathrm{C}$

Total biaya produksi/bulan $=$ fixed cost/bulan + variabel cost

\section{Rumus Harga Produksi Perunit :}

$$
\mathrm{A}=\frac{B}{C}
$$

Harga pokok produksi/unit $=\frac{\text { total biaya produksi perbulan }}{\text { jumlah produksi yang dihasilkan perbulan }}$

\section{Payback Period (PP)}

Suatu periode yang diperlukan untuk menutup kembali pengeluaran investasi (initial cast investment) dengan menggunakan aliran kas, dengan kata lain payback period merupakan rasio antara initial cast investment dengan cast inflow-nya yang hasilnya merupakan satuan waktu. Selanjutnya nilai rasio ini dibandingkan dengan maximum payback period yang akan diterima.

Payback Period $=\frac{\text { Nilai Investasi }}{\text { Kas masuk bersih }} \times 1$ tahun 


\section{Return on Investment (ROI)}

$\mathrm{ROI}=\frac{\text { Laba perbulan }}{\text { Total investasi }} \times 100 \%$

\section{PEMBAHASAN}

\section{Resep Hasil Penelitian}

Untuk melakukan uji perbandingan formulasi Brownies Bakar Berbasis Tepung Kacang Merah dengan substitusi tepung kacang merah sebagai bahan baku dan uji daya terima konsumen. Peneliti memilih 15 panelis ahli yang berbeda untuk menguji tiga sampel produk brownies bakar berbasis tepung kacang merah. Tiga sampel tersebut mempunyai formulasi yang berbeda. Produk brownies bakar berbasis tepung kacang merah dengan konsentrat terbaik yaitu: 20 gr flour dan $40 \mathrm{gr}$ tepung kacang merah. Berikut adalah resep produk inovasi brownies bakar berbasis tepung kacang merah :

\section{Resep Brownies Bakar Tepung Kacang Merah (BTKM2)}

Waktu Penyajian : 60 menit

\begin{tabular}{|c|c|c|c|c|}
\hline Preparation & Ingridient & Unit & Qty & Remark \\
\hline $\begin{array}{l}\text { Pembuatan } \\
\text { Tepung } \\
\text { Kacang } \\
\text { Merah }\end{array}$ & Kacang merah & $\mathrm{Kg}$ & 1 & $\begin{array}{l}\text { Kacang merah yang } \\
\text { sudah kering di blender } \\
\text { hingga halus lalu di } \\
\text { ayak. } 1 \text { kg kacang } \\
\text { merah menghasilkan } \\
500 \text { gr tepung kacang } \\
\text { merah. }\end{array}$ \\
\hline \multirow{8}{*}{$\begin{array}{l}\text { Adonan } \\
\text { Brownies } \\
\text { Bakar }\end{array}$} & Tepung terigu & $\mathrm{Gr}$ & 20 & \multirow{4}{*}{$\begin{array}{l}\text { Ayak hingga halus dan } \\
\text { satukan semua bahan }\end{array}$} \\
\hline & $\begin{array}{l}\text { Tepung } \\
\text { kacang merah }\end{array}$ & $\mathrm{Gr}$ & 40 & \\
\hline & $\begin{array}{l}\text { Baking } \\
\text { powder }\end{array}$ & Sdt & 1 & \\
\hline & $\begin{array}{l}\text { Coklat } \\
\text { powder }\end{array}$ & Sdt & 2 & \\
\hline & Telur & Butir & 3 & \multirow{2}{*}{$\begin{array}{l}\text { Kocok hingga } \\
\text { mengembang }\end{array}$} \\
\hline & Gula pasir & $\mathrm{Gr}$ & 100 & \\
\hline & Margarin & $\mathrm{Gr}$ & 90 & \multirow[t]{2}{*}{ Lelehkan } \\
\hline & Coklat batang & $\mathrm{Gr}$ & 100 & \\
\hline \\
\hline \multicolumn{5}{|c|}{$\begin{array}{l}\text { Tahap pembuatan brownies bakar berbasis tepung kacang merah: } \\
\text { 1. Tim coklat batang bersama margarin, aduk hingga meleleh, sisihkan. } \\
\text { 2. Kocok telur dan gula dengan mixer hingga mengembang. } \\
\text { 3. Masukkan tepung terigu, tepung kacang merah, baking powder dan coklat } \\
\text { powder, aduk dengan spatula hingga rata. } \\
\text { 4. Tuang coklat batang yang telah dilelehkan, aduk balik dengan spatula } \\
\text { hingga rata. } \\
\text { 5. Olesi loyang dengan margarin yang berbentuk persegi panjang. } \\
\text { 6. Tuang adonan ke dalam loyang berbentuk persegi panjang. }\end{array}$} \\
\hline
\end{tabular}


7. Panggang dalam oven $180{ }^{\circ} \mathrm{C}$ selama kurang lebih 20 menit.

Sumber : Noormindhawati (2014), dalam buku Brownies

Hasil Uji Hedonik (Kesukaan)

Hasil rata-rata uji hedonik 2 sampel keseluruhan

\begin{tabular}{|c|l|c|c|}
\hline \multirow{2}{*}{ No. } & \multicolumn{2}{|c|}{ Keterangan } & \multicolumn{2}{c|}{ Kode Sampel } \\
\cline { 3 - 4 } & & BTKM2 & Kontrol \\
\hline 1. & Warna & 3,77 & 3,52 \\
\hline 2. & Rasa & 4,18 & 3,80 \\
\hline 3. & Aroma & 4,08 & 3,65 \\
\hline 4. & Tekstur & 3,82 & 3,58 \\
\hline 5. & Penampilan fisik & 3,52 & 3,56 \\
\hline
\end{tabular}

Sumber : Data diolah, September 2015

Berdasarkan Tabel diatas dilihat antara produk inovasi dan produk kontrol, produk brownies bakar berbasis tepung kacang merah dapat diterima di masyarakat.

\section{Penilaian Tanggapan Responden Daya Terima Konsumen}

Pada tahap ini merupakan tahapan dimana responden menanggapi dan menilai produk yang telah dicoba. Penilaian dilihat dari aspek tingkat kesukaan warna, rasa, aroma, tekstur dan penampilan fisik.

Berdasarkan total skor dari hasil pengumpulan data pada variabel daya terima konsumen BTKM2 sebanyak 1952 .Dapat dilihat pada tabel berikut:

\section{Kelas Interval Daya Terima Konsumen}

\begin{tabular}{|c|c|}
\hline Skor & Keterangan \\
\hline $500-900$ & Sangat tidak diterima \\
\hline $901-1301$ & Tidak diterima \\
\hline $1302-1702$ & Kurang diterima \\
\hline $1703-2103$ & Diterima \\
\hline $2104-2504$ & Sangat diterima \\
\hline
\end{tabular}

Sumber : Data diolah, September 2015

\section{Penilaian Responden Terhadap Minat Beli Konsumen}

Penelitian ini tidak hanya diujikan dengan daya terima konsumennya saja tetapi juga diuji mengenai minat beli konsumen terhadap produk brownies bakar berbasis tepung kacang merah. Berikut merupakan hasil penilaian responden terhadap minat beli konsumen:

Harga brownies bakar berbasis tepung kacang merah menurut konsumen

\begin{tabular}{|c|l|c|c|}
\hline No. & \multicolumn{1}{|c|}{ Harga } & Frekuensi & Presentase \% \\
\hline 1. & Rp25.500,- & 34 & $34 \%$ \\
\hline 2. & Rp26.500,- & 33 & $33 \%$ \\
\hline 3. & Rp27.500,- & 20 & $20 \%$ \\
\hline
\end{tabular}




\begin{tabular}{|c|c|c|c|}
\hline 4. & Rp28.500,- & 13 & $13 \%$ \\
\hline \multicolumn{2}{|c|}{ Total } & $\mathbf{1 0 0}$ & $\mathbf{1 0 0 \%}$ \\
\hline
\end{tabular}

Sumber : Data diolah, September 2015

Berdasarkan Tabel 4.31 diatas, harga yang sesuai menurut konsumen terhadap produk brownies bakar berbasis tepung kacang merah dengan harga $\mathrm{Rp} 25.500$,-/porsi sebanyak 34 orang, harga Rp 26.500,-/porsi sebanyak 33 orang, harga Rp 27.500,/porsi sebanyak 20 orang, dan harga Rp 28.500,-/porsi sebanyak 13 orang.

Setuju atau tidak harga brownies Rp 25.500,- menurut konsumen

\begin{tabular}{|c|l|c|c|}
\hline No. & \multicolumn{1}{|c|}{ Minat Beli } & Frekuensi & Presentase \% \\
\hline 1. & Setuju & 52 & $52 \%$ \\
\hline 2. & Tidak Setuju & 48 & $48 \%$ \\
\hline \multicolumn{2}{|c|}{ Total } & $\mathbf{1 0 0}$ & $\mathbf{1 0 0} \%$ \\
\hline
\end{tabular}

Sumber : Data diolah, September 2015

Berdasarkan Tabel 4.32 diatas, dari 100 responden yang setuju terhadap harga brownies bakar berbasis tepung kacang merah sebesar Rp 25.500,-/porsi sebanyak 52 orang dan yang tidak setuju sebanyak 48 orang.

Studi Kelayakan Bisnis

Kebutuhan Bahan Baku

\begin{tabular}{|c|l|c|c|c|c|c|c|}
\hline $\begin{array}{c}\text { N } \\
\text { o }\end{array}$ & Bahan Baku & Qty & Unit & Jumlah Perunit & Unit & $\begin{array}{c}\text { Price/ } \\
\text { unit } \\
(\mathbf{R p})\end{array}$ & $\begin{array}{c}\text { Jumlah } \\
\text { Biaya } \\
(\mathbf{R p})\end{array}$ \\
\hline 1. & Tepung terigu & 20 & Gr & 250 & gr & 3.500 & 280 \\
\hline 2. & Kacang merah & 40 & Gr & 250 & gr & 5.000 & 800 \\
\hline 3. & Margarin & 90 & Gr & 250 & gr & 4.000 & 1.440 \\
\hline 4. & Telur & 3 & btr & 8 & btr & 12.000 & 4.500 \\
\hline 5. & Coklat batang & 100 & Gr & 1000 & gr & 47.000 & 4.700 \\
\hline 6. & Coklat bubuk & 15 & Gr & 45 & gr & 8.000 & 2.666 \\
\hline 7. & Baking powder & 10 & Gr & 45 & gr & 5.000 & 1.111 \\
\hline 8. & Gula & 100 & Gr & 250 & gr & 4.000 & 1.600 \\
\hline \multicolumn{7}{|c|}{ Total } \\
\hline
\end{tabular}

Biaya Bahan Baku (BTKM2) untuk 1 porsiporsi

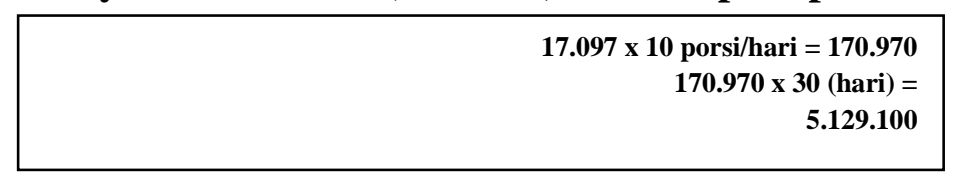

Sumber : Data diolah, September 2015 


\section{Kebutuhan Peralatan dan Outlate Usaha}

Biaya Peralatan dan Perlengkapan

\begin{tabular}{|c|l|c|c|c|}
\hline No. & \multicolumn{1}{|c|}{ Keterangan } & $\begin{array}{c}\text { Jumlah } \\
\text { Unit }\end{array}$ & $\begin{array}{c}\text { Harga } \\
(\text { Rp) }\end{array}$ & Jumlah \\
\hline 1. & Meja Kayu & 2 & 500.000 & 1.000 .000 \\
\hline 2. & Kursi kayu & 4 & 100.000 & 400.000 \\
\hline 3. & Kompor & 1 & 350.000 & 350.000 \\
\hline 4. & Oven & 1 & 250.000 & 250.000 \\
\hline 5. & Mixer & 1 & 200.000 & 200.000 \\
\hline 6. & Timbangan & 1 & 100.000 & 100.000 \\
\hline 7. & Panci alumunium & 1 & 35.000 & 35.000 \\
\hline 8. & Spatula karet & 1 & 5.000 & 5.000 \\
\hline 9. & Loyang & 4 & 8.000 & 32.000 \\
\hline 10. & Sendok & 2 & 2.000 & 4.000 \\
\hline 11. & Kuas & 1 & 5.000 & 5.000 \\
\hline 12. & Pisau & 1 & 30.000 & 30.000 \\
\hline 13. & Kertas roti & 3.000 & 3.000 \\
\hline \multicolumn{4}{|l|}{ TOTAL } & $\mathbf{2 . 4 1 4 . 0 0 0}$ \\
\hline
\end{tabular}

Sumber : Data diolah, September 2015

Pada Tabel diatas, total biaya yang dibutuhkan untuk peralatan dan perlengkapan sebesar Rp 2.414.000,-

Biaya Penunjang Usaha

\begin{tabular}{|c|l|c|c|c|}
\hline No. & \multicolumn{1}{|c|}{ Keterangan } & Unit & Harga (Rp) & Jumlah Harga (Rp) \\
\hline 1. & Gas & 1 unit $(3 \mathrm{~kg})$ & $13.000 /$ tabung & 1.300 \\
\hline 2. & Kemasan & 1 buah & 2.000 & 2.000 \\
\hline \multicolumn{4}{|c|}{ TOTAL } \\
\hline
\end{tabular}

Sumber: Data diolah, September 2015

Biaya penunjang usaha pada Tabel diatas sebesar Rp 3.300,-/pax hasil tersebut didapat dari gas dan kemasan.

Biaya Tetap (Fixed Cost)

\begin{tabular}{|c|l|l|c|c|}
\hline $\begin{array}{c}\text { No } \\
\cdot\end{array}$ & \multicolumn{1}{|c|}{ Keterangan } & Unit & Harga (Rp) & Jumlah Harga (Rp) \\
\hline 1. & Biaya Listrik & 1 bulan & 100.000 & 100.000 \\
\hline 2. & Biaya Air & 1 bulan & 120.000 & 120.000 \\
\hline 3. & Sewa Tempat & 1 bulan & 500.000 & 500.000 \\
\hline 4. & Biaya Transportasi & 1 bulan & 100.000 & 100.000 \\
\hline \multicolumn{4}{|c|}{ TOTAL } & $\mathbf{8 2 0 . 0 0 0}$ \\
\hline
\end{tabular}

Sumber: Data diolah, September 2015

Biaya Tetap pada Tabel diatas sebesar Rp 820.000,-/bulan hasil tersebut

didapat dari biaya listrik, biaya air, biaya sewa tempat, dan biaya transportasi.

\section{Biaya Variabel Cost}




\begin{tabular}{|c|c|c|}
\hline No. & Keterangan & Jumlah (Rp) \\
\hline 1. & Total Bahan Baku & Rp 17.097,-/pax \\
\hline 2. & Biaya Penunjang Usaha & Rp 3.300,-/pax \\
\hline \multicolumn{2}{|c|}{ TOTAL } & Rp 20.397,-/pax \\
\hline
\end{tabular}

Sumber: Data diolah, September 2015

Perhitungan pada Tabel diatas, biaya variabel cost sebesar Rp 20.397,-/pax. Berikut merupakan rincian harga jual Brownies Bakar Tepung Kacang Merah, yaitu :

Perhitungan Harga Jual Brownies Bakar Berbasis Tepung Kacang Merah

\begin{tabular}{|l|c|}
\hline \multicolumn{1}{|c|}{ Perhitungan } & Harga Jual Rp 25.500,- \\
\hline Food Cost (30\%) & Rp 7.650,- \\
\hline Labour (30\%) & Rp 7.650,-- \\
\hline Over Head (20\%) & Rp 5.100,- \\
\hline Profit(20\%) & Rp 5.100,- \\
\hline \multicolumn{1}{|c|}{ Perhitungan } & Harga Jual Rp 26.500,- \\
\hline Food Cost (30\%) & Rp 7.950,-- \\
\hline Labour (30\%) & Rp 7.950,- \\
\hline Over Head (20\%) & Rp 5.300,-- \\
\hline Profit(20\%) & Rp 5.300,-- \\
\hline \multicolumn{1}{|c|}{ Perhitungan } & Harga Jual Rp 27.500,- \\
\hline Food Cost (30\%) & Rp 8.250,-- \\
\hline Labour (30\%) & Rp 5.500,-- \\
\hline Over Head (20\%) & Rp 5.500,- \\
\hline Profit(20\%) & Harga Jual Rp 28.500,- \\
\hline \multicolumn{1}{|c|}{ Perhitungan } & Rp 8.550,-- \\
\hline Food Cost (30\%) & Rp 8.550,- \\
\hline Labour (30\%) & Rp 5.700,- \\
\hline Over Head (20\%) & Rp 5.700,- \\
\hline Profit(20\%) &
\end{tabular}

Sumber: Data diolah, September 2015

Berdasarkan Tabel diatas, apabila produk Brownies Bakar Tepung Kacang Merah dijual dengan harga Rp 25.500,-/pax maka keuntungan yang didapat sebesar Rp 5.100,- ,apabila produk dijual dengan harga Rp 26.500,-/pax maka keuntungan yang didapat sebesar Rp 5.300,- , apabila produk dijual dengan harga Rp 27.500,-/pax maka keuntungan yang didapat sebesar Rp 5.500,-, dan apabila produk dijual dengan harga $\mathrm{Rp} 28.500,-/$ pax maka keuntungan yang didapat sebesar Rp 5.700,-.

\subsubsection{Analisis Titik Impas}

\section{Perhitungan Break Event Point (BEP) perunit}

$$
\begin{aligned}
\text { BEP perunit } & =\frac{\text { Total biaya tetap }}{\text { Harga jual perunit }- \text { Biaya Variabel perunit }} \\
& =\frac{\mathrm{Rp} \mathrm{820.00,-}}{\operatorname{Rp} 25.500,-\operatorname{Rp} 20.397}
\end{aligned}
$$


$=\frac{160}{30}$ unit $/$ bulan

$=5$ unit

\section{Perhitungan Break Event Point (BEP) Rupiah}

$$
\begin{aligned}
\mathrm{BEP}(\mathrm{Rp}) & =\frac{\text { Total biaya tetap }}{\text { Kontribusi margin perunit/Harga jual perunit }} \\
=\mathrm{Rp} 4.100 .000,- & \frac{\mathrm{Rp} 820.00,-}{\operatorname{Rp} 5.100, / \mathrm{Rp} 25.500,}
\end{aligned}
$$

\subsubsection{Analisis Kelayakan Usaha}

Hasil ini digunakan sebagai bahan pertimbangan dalam mengambil keputusan menerima atau menolak suatu rencana usaha.

1. Payback Period (PP)

$$
\begin{aligned}
\text { Payback Period } & =\frac{\text { Total Investasi }}{\text { Laba perbulan }} \\
& =\frac{R p 3.000 .000,-}{R p 5.100 \times 7 \text { brownies } \times 30 \text { hari }} \\
& =\frac{R p 3.000 .000,-}{R p 1.071 .000}
\end{aligned}
$$

$=2$ bulan 2 hari

Jadi, jangka waktu nilai pengembalian investasi usaha akan dicapai 2 bulan 2 hari dari waktu operasional.

\section{Return On Investment (ROI)}

$$
\begin{aligned}
& \mathrm{ROI}=\frac{\text { Laba perbulan }}{\text { Total investasi }} \times 100 \% \\
& =\frac{R p 1.071 .000,-}{R p 3.000 .000,-} \times 100 \% \\
& =35 \%
\end{aligned}
$$

Jadi, persentase return on investment usaha sebesar 35\% dari investasi. Maka laba yang didapat dari total investasi usaha sebesar 35\% dari total penjualan brownies bakar tepung kacang merah.

\section{KESIMPULAN}

Berdasarkan dari hasil pengamatan dan eksperimen analisis daya terima konsumen dan studi kelayakan bisnis produk Brownies Bakar Berbasis Tepung Kacang Merah dapat disimpulkan sebagai berikut:

1. Kacang merah yang digunakan adalah kacang merah yang berkualitas baik dan tidak busuk. Kacang merah yang telah dipilih lalu dicuci dengan menggunakan air bersih sehingga tidak ada kotoran yang menempel. Kacang merah yang telah bersih, selanjutnya dibelah menjadi dua bagian gunanya agar kacang merah cepat kering dalam proses penjemuran dibawah sinar matahari. Kacang merah yang sudah kering lalu di blender hingga lembut selanjutnya di ajak sehingga berupa tepung. 
2. Berdasarkan formulasi tepung terigu ( $30 \mathrm{gr}, 20 \mathrm{gr}, 40 \mathrm{gr}$ ) dicampur dengan tepung kacang merah (30 gr, 40 gr, 20 gr) sehingga total dari masing-masing formulasi yang telah dicampur sebanyak 60 gr. Tim 100 gr coklat batang bersama 90 gr margarin aduk hingga meleleh lalu sisihkan, kocok 3 butir telur dan 100 gr gula dengan mixer hingga mengembang, masukkan masing-masing formulasi tepung dan baking powder 1 sdt tidak lupa coklat powder 2 sdt aduk dengan spatula hingga rata, tuang coklat batang yang telah dilelehkan lalu aduk balik dengan spatula hingga rata, tuang adonan ke dalam loyang berbentuk persegi panjang yang sebelumnya loyang telah diolesi margarin, panggang dalam oven $180^{\circ} \mathrm{C}$ selama kurang lebih 30 menit.

3. Respon daya terima konsumen terhadap inovasi produk brownies bakar berbasis tepung kacang merah cukup baik. Sekitar 58 orang menyukai rasa dari brownies bakar berbasis tepung kacang merah ini. Produk inovasi ini dapat dikatakan berhasil karena hampir seluruh konsumen menyukai produk inovasi brownies bakar berbasis tepung kacang merah ini.

4. Kelebihan dari brownies bakar berbasis tepung kacang merah yaitu meningkatkan nilai gizi, lebih banyak protein nabatinya, non gluten (tidak banyak mengandung gluten), dan produk brownies bakar yang menggunakan tepung kacang merah belum ada di pasaran, sedangkan kekurangan brownies bakar berbasis tepung kacang merah vaitı tidak semua konsumen menyukai rasa dan aroma kacang merah.

5. Berdasarkan hasil penilaian respo rhadap minat beli konsumen produk brownies bakar berbasis tepung kacang merah dari 100 responden, 58 orang menunjukkan bahwa bersedia untuk membeli produk tersebut. Hasil penilaian mengenai harga yang sesuai dengan produk tersebut, dari 100 responden 34 orang yang memilih harga Rp 25.500,-/porsi. Menurut para responden harga tersebut merupakan harga yang terjangkau untuk produk brownies bakar.

\section{A. DAFTAR PUSTAKA}

Astawan, Made. 2009. Sehat dengan Hidangan Kacang dan Biji-bijian, Penebar Swadaya, Jakarta.

Afrianti, Herliani, Leni. 2008. Teknologi Pengawetan Pangan, Alfabeta, Bandung.

Bartono. 2000. Pengantar Pengolahan Makanan, PT Pertja, Jakarta.

Bartono dan Ruffino E.M. 2005. Food Product Management di Hotel dan Restoran, CV ANDI offset, Yogyakarta.

Effendi, Supli. 2009. Teknologi Pengolahan dan Pengawetan Pangan, Alfabeta, Bandung.

Herudiyanto, S Marleen. 2008. Pengantar Teknologi Pengolahan Pangan, Widya Padjadjaran, Bandung.

Johan, Suwinto. (011. Studi Kelayakan Pengembangan Bisnis, Graha Ilmu, Yogyakarta.

Khomsan, Ali. 2006. Solusi Makanan Sehat, PT Raja Grafindo, Jakarta.

Minantyo, Hari. 2011. Dasar-Dasar Pengolahan Makanan, Graha Ilmu, Yogyakarta. Muljadi. 2009. Kepariwisataan dan Perjalanan, Rajawali Pers, Jakarta.

Noormindhawati, Lely. 2014. Brownies, Dunia Kreasi, Jakarta. 
Schiffman dan Kanuk. 2007. Perilaku Konsumen, PT Gramedia, Jakarta.

Setyaningsih, Dwi, dkk. 2010. Analisis Sensori untuk Industri Pangandan Agro, IPB Press, Bogor.

Siregar, Syofian. 2013. Statistik Parametrik Untuk Penelitian Kuantitatif, Bumi Aksara, Jakarta.

Soekarto, T Soewarno. 1985. Penilaian Organoleptik Untuk Industri Pangandan Hasil Pertanian, Bhratara Karya Aksara, Bogor.

Suhardjito. 2006. Pastry Dalam Perhotelan, ANDI, Yogyakarta.

Sugiyono. 2014. Statistika Untuk Penelitian, Alfabeta, Bandung.

Shewfelt, L Robert. 2014. Pengantar Ilmu Pangan, Buku Kedokteran EGC, Jakarta.

Septiani, Dwi Adhita. 2014. Inovasi Produk Kue Tradisional Ali Agrem Menggunakan Bahan Dasar Tepung Ubi Ungu. Skripsi. Jurusan Manajemen Industri Katering. Fakultas Pendidikan Ilmu Pengetahuan Sosial. Universitas Pendidikan Indonesia. Bandung : Tidak Diterbitkan.

Saputra, Adi Gita.

http://googleweblight.com/?lite_url=http://www.satwa.net/890/mengenal-

kacang-merah.html\&ei=ZfLQ45-1\&lc=id-

$I D \& s=1 \& m=805 \& t s=1437981764 \&$ sig $=$ AKQ9UO-ON2qtosmlXow7a9-

zht7CRP380g (di akses 27 Juli 2015).

Umar, Husein. 1997. Studi Kelayakan Bisnis, Gramedia Pustaka Utama. Jakarta.

Undang-Undang Pariwisata, Www.Wisatakandi.com/2011/11/Undang-Undang-RINo-10-Tahun-2009.html? $m=1$ (di akses 29 Juni 2015)

Wiramihardja, K Kunkun. 2004. Obesitas dan Penanggulangannya, Granada.

Warsito, Heri, dkk. 2015. Ilmu Bahan Makanan Dasar, Nuha Medika, Yogyakarta.

Yuliana, Dina. 2013. Analisis Daya Terima Konsumen Choux Pastry Berbasis

Penambahan Tepung Talas Sebagai Substituen Bahan Baku. Skripsi. Jurusan Manajemen Industri Katering. Fakultas Pendidikan Ilmu Pengetahuan Sosial. Universitas Pendidikan Indonesia. Bandung : Tidak Diterbitkan. 